\title{
LITERATURA ESPAÑOLA DE TERROR: LEYENDO ALGUNOS RELATOS BREVES VERDADERAMENTE ESTREMECEDORES
}

No son muchas las publicaciones y ediciones que hagan referencia a la existencia de una literatura española de terror. Para el lector español, el terror más conocido desde el punto de vista literario, suele ser el procedente de otra literaturas europeas o americanas, en particular la anglosajona, con Edgar Allan Poe a la cabeza, pero sin olvidar a Charles Dickens, Bram Stoker, Ambrose Bierce, Howard Lovecraft, ni a algunos de otras literaturas europeas, particularmente famosos como Donatien Alphonse Franšois de Sade o Charles Nodier. Pero no es difícil encontrar entre los escritores españoles algunos cuentos de terror que nos hablan con todo rigor de la existencia de una literatura española de terror, aún en gran parte por investigar.

Nos vamos a referir en este ensayo a algunos ejemplos que ya recogió Rafael Llopis en los años sesenta en una Antología de cuentos de terror, que sigue teniendo en su fondo Alianza Editorial en sus libros de bolsillo, y, en concreto, últimamente, en su Biblioteca Temática de «Fantasía y terror». En tal colección se pueden leer los relatos a los que nos vamos a referir en este panorama de la literatura española de terror ${ }^{1}$.

Y comenzamos por un auténtico clásico del género. Un texto nada menos que de Lope de Vega, perteneciente a su novela El peregrino en su patria, clásico ya en el género desde que el británico del siglo XIX, vendedor de Biblias y gran conocedor de la cultura española, George Borrows, lo consideró el mejor cuento de miedo que jamás se había escrito. En realidad no es un cuento suelto, sino un fragmento en el que se recoge una de las numerosas aventuras de Pánfilo, protagonista de la novela bizantina o de aventuras de Lope de Vega, y que se le ha dado el título de «La posada de mal hospedaje».

El relato tiene lugar cuando Pánfilo, una vez abandonada Zaragoza, sigue el camino de sus aventuras, y una noche, «fatigado de la aspereza de los montes y la rusticidad del sustento» decide buscar posada en una villa, y no hallándola se dirige al hospital del lugar que encuentra desierto y oscuro debido a que había muerto un extranjero por lo que le recomiendan que se entrase en una capilla, donde había un santo varón que le daría posada y cobijo, a pesar de que el viejo le avisa del «mal hospedaje de esta casa». Le acompaña, tras atravesar un jardín, que más parecía bosque, hasta un cuarto apartado, en el que Pánfilo se instala y se duerme tras cambiarse y acomodarse. Una vez dormido sucede lo siguiente:

\footnotetext{
1 Seguimos para nuestras citas esta antología, en su edición de 2004. La edición está distribuida de la siguiente forma: Volumen I. Relatos de Lope de Vega, Daniel Defoe, Donatien Franšois de Sade, Walter Scott, Matthew Gregory Lewis, Charles Nodier, Frederik Marryat, John William Polidori, Agustín Pérez-Zaragoza y Edgar Allan Poe. -Volumen II. Relatos de Charles Dickens, Joseph Sheridan La Fanu, Margaret Oliphant, Pedro Antonio de Alarcón, Gustavo Adolfo Bécquer, Ambrose Bierce, Bram Stoker y Montague Rhodes James. - Volumen III. Relatos de Arthur Menchen, Algeron Blackwoood, Oliver Onions, Wenceslao Fernández Flórez, Howard Phillip Lovecraft, Noel Clarasó. La antología contó con muchas ediciones anteriores: Madrid: Taurus, 1963. Madrid: Alianza Editorial, 1981, 1982, 1985, 1988, 1993, 1994, 1997, 2000. Última edición, en Biblioteca Temática de «Fantasía y terror», Madrid: Alianza Editorial, 2004.
} 
La parte que desampara el sol cuando se va a los indios estaba en profundo silencio, cuando al ruido de algunos caballos despertó Pánfilo; parecióle que caminaba -cosa que a los que caminan siempre sucede-, que la cama se mueve como la nave, o anda como el caballo que traía; pero acordándose que estaba en aquel hospital, y advertido del escándalo, por cuya causa era inhabitable, abrió los ojos y vio que como si entraran a jugar cañas, de dos en dos entraban a caballo algunos hombres, alguno de los cuales, encendiendo unas ventosas de vidrio, que traían en las manos, en la vela que habían dejado, las iban tirando al techo del aposento, donde se clavaban, y quedaban ardiendo por largo tiempo, quedando el suelo pegado a las tablas, y la boca vertiendo llamas sobre la cama y lugar donde había puesto los vestidos. Se cubrió el animoso mancebo lo mejor que pudo, y dejando un pequeño resquicio a los ojos para que le avisasen si le convenía guardarse del comenzado incendio, vio en un instante las llamas muertas, y que en una mesa, que a la esquina de la sala estaba, se comenzaba un juego de primera, entre cuatro; pasaban, descartábanse, y metían dineros, como si realmente pasara de veras, y habiéndose enojado los jugadores, se trabó una cuestión en el aposento, con tantos golpes de espadas y broqueles, que el mísero Pánfilo comenzó a llamar a la Virgen de Guadalupe, que sólo le faltaba de visitar en España, aunque era del reino de Toledo; porque las cosas que están muy cerca, pensando verse cada día, suelen dejar de verse muchas veces. Pero cesando el golpear de las espadas, y todo el ruido por media hora, quedó de un sudor ardiente bañado el cuerpo en agua, y estando -a su parecer- satisfecho, que ya no volverían, sintió que asiendo los dos extremos de la colcha y sábanas, se las iban quitando poco a poco. Aquí fue notable su temor, pareciéndole que ya se le atrevían a la persona, pues le quitaban la defensa, y estando de esta suerte, vio entrar con un hacha un hombre, detrás del cual venían dos, el uno con una bacía grande de metal, y el otro afilando un cuchillo; se le erizaron los cabellos en esta sazón, de tal suerte que le pareció que de cada uno de por sí le iban tirando. Quiso hablar y no pudo pero cuando a él se acercaron, el que traía el hacha la mató de un soplo, pensando que entonces le degollarían, y que aquella bacía era para coger su sangre, fue a detener con las manos el cuchillo, adonde le pareció que le había visto, y sintió que se las tragaron a un mismo tiempo. Dio un grito Pánfilo; y en este instante se volvió a encender el hacha, y vio que dos grandes perros se las tenían asidas. «Jesús», dijo turbado, a cuya voz se metieron debajo de la cama, y vuelta a matar la luz, sintió que le ponían ropa como primero, y que, alzándole de la cabeza, le acomodaban mejores almohadas, y le igualaban, con grande aseo, curiosidad y regalo, la sábana y colcha. (Lope de Vega, 2004: 19-20)

Como advertimos, los elementos fantásticos y de terror se suceden en esta especie de visión infernal que está sufriendo el pobre peregrino en su patria, incapaz de entender lo que está sucediendo, y aunque parece que ha llegado a un momento de reposo, tras decir la palabra «Jesús», no es así. Su terror le hace continuar rezando, ante visiones tan fantasmagóricas:

Así le dejaron estar un rato, en el cual comenzó a rezar algunos versos de David, de que se acordaba -si entonces se podía acordar de sí mismo- y recobrando aliento, con alguna confianza de que, habiéndole compuesto la cama le dejarían en ella, vio que los que debajo de ella se habían entrado, le iban levantando por las espaldas, con su persona encima, hasta llegar al techo, donde, como si temiese la caída, sintió que de las mismas tablas le asía una mano del brazo, y cayendo la cama al suelo, con espantoso golpe, quedó colgado en el aire, de aquella mano, y que alrededor de la sala se habían 
abierto cantidad de ventanas, desde donde le miraban muchos hombres y mujeres con notable risa, y con algunos instrumentos le tiraban agua. Se ardió la cama en este punto, y así la llama de ella le enjugaba, aunque con mayor miedo que al agua había tenido. Cesó la luz de aquel fuego, y tirándole de las piernas, también le pareció que le faltaban, y que había quedado el cuerpo tronco, y sin ellas. Fuese a este tiempo alargando el brazo, que le tenía asido, hasta la cama, donde otra vez de nuevo le acostaron y regalaron como primero. (Lope de Vega, 2004: 20)

Sigue a esto el descanso, el robo de las alforjas, la salida al huerto, el arrojarse con lo robado por una noria, y la llamada de Pánfilo a la habitación del viejo que le acoge hasta la mañana siguiente. Y antes se ha preguntado el narrador (Lope de Vega): «¿Quién creerá lo que digo?» Para reflexionar después: «Muchos que ignoran la calidad de los espíritus, su naturalezas y condiciones, tendrán esta historia mía por fábula.»Y el buen Lope, escritor de su época al fin, y religioso por demás, justifica la existencia de unos espíritus que son capaces de alterar la paz de los ciudadanos, víctimas algunos de ellos, sólo algunos, de las travesuras y caprichos de estos seres de otro mundo que:

pueden dañar y ofender poco, pero sólo toman placer en hacer algunos estrépitos y rumores de noche, burlas, juegos y otras cosas semejantes, los cuales son oídos y vistos por algunos, como se sabe de muchos lugares y casas, las cuales son turbadas de tales escándalos, hechos de los demonios, echando piedras, o molestando los hombres con golpees, encendiendo fuego o haciendo otras operaciones delusorias. Estas cosas hacen estos muchas veces; porque no pueden ofender a los hombres de otra manera que con estos efectos ridículos e inútiles, constreñidos y ligados del infinito poder de Dios. (Lope de Vega, 2004: 21)

Llegada la mañana, salen Pánfilo y el viejo del aposento donde aquél había sido acogido, cruzan el huerto y acuden a la habitación primera donde había intentado dormir con la intención de ver el estrago de la pasada noche, pero lo que encuentran es muy distinto: «hallaron la cama y las demás cosas del aposento sin lesión alguna, y la ropa de Pánfilo en el mismo lugar donde la había puesto». De lo que sin duda el propio Pánfilo sufrió gran vergüenza, pensando que su huésped le consideraría «fabuloso y hombre de poco ánimo», por lo que con la debida licencia del viejo continuó su viaje y sus peregrinaciones.

Sin duda, Lope de Vega, de forma muy excepcional en su novela El peregrino en su patria, introdujo un relato de terror y fantástico muy singular en su tiempo, y desde luego, digno precedente de tantas páginas españolas en las que la literatura de terror tiene su asiento. Los elementos sin duda fantasmagóricos y sobrenaturales, imaginados por Lope de Vega, y acumulados repentinamente en el relato, producen los efectos apetecidos de sobrecogimiento y pavor para el lector de este tipo de novelas de aventuras, aunque también hay que señalar que tales excesos no eran habituales en este tipo de novelas. Por ello, se le otorga a Lope un puesto de honor como precedente de la literatura española de terror, tan sólo por este episodio intercalado en su novela bizantina, y no es extraño, desde luego, que el buen George Borrows lo considerara un excelente cuento de miedo, «el mejor que jamás se había escrito».

Un escritor, del que sabemos muy poco, Agustín Pérez Zaragoza, que debió de vivir a finales del siglo XVIII y principios del siglo XIX, dejó escrita una obra titulada Galería fúnebre de espectros y sombras, impreso en 1831, en la que figura un relato escalofrian- 
te y muy representativo de la novela gótica, que se extendió por Europa a principios del siglo XIX. Un admirador suyo fue Ramón de Mesonero Romanos, que consideró que ésta era la única obra divertida publicada en aquellos años.

El relato, titulado «La princesa de Lipno o el retrete del placer criminal», nos cuenta la historia de un perverso conde ruso Dourlinski, que, a pesar de sus buenas proporciones físicas y sus muchas riquezas resultó ser un malévolo asesino y criminal. Casado en primeras nupcias con la Condesa Niesiska, a la que había asesinado, contrae segundas nupcias con la joven princesa de Lipno, Elvira. Tras la boda, realizada únicamente por intereses territoriales y de poder, la joven princesa encarcelada en un castillo tal como relata Pérez Zaragoza no sin exacerbado dramatismo:

La hermosa Elvira, nuestra joven princesa, privada ya de los consejos de su madre y de su padre, acompañada de una servidumbre poco numerosa, y no teniendo a su lado más que a un escudero, Beniski, y Narcisa, su camarera italiana de nacimiento, estaba enteramente entregada sin defensa alguna a su verdugo, a su asesino, así como por una tierna paloma inútilmente agachada bajo la hierba se ve amenazada por las garras de un feroz gavilán: no porque la faltase valor ni penetración: pero ¿cómo podía jamás sospechar que el conde, hombre generalmente estimado, fuese un malhechor, un asesino? (Pérez Zaragoza, 2004: 215)

El escenario en el que va a vivir la desdichada joven princesa no es sino un espacio propicio para el terror, lo que la recién casada va advirtiendo poco a poco:

De todos modos, Elvira no había ocultado a Narcisa, su estimada confidenta, lo poco que le agradaba la localidad del castillo, sus contornos, su soledad, los silbidos que había oído a ciertas horas de la noche... y, en fin, los grandes fosos de que estaba rodeado, cuyas circunstancias reunidas la desagradaban bastante y la causaban mucha inquietud; tampoco la disimuló las observaciones que había hecho sobre la distribución de los cuartos, las muchas escaleras falsas, y aquella longitud silenciosa de los corredores, que en su imaginación tenían mucho misterio y melancolía, y desde luego parecía debían haberse hecho con siniestras intenciones, cuya causa sólo podía ella definir interiormente. (Pérez Zaragoza, 2004: 215)

Una noche, que Dourlinski había salido a cazar osos, el terror va aumentando y se apodera de la joven princesa, que empieza a oír gemidos subterráneos, luces excesivas, resplandores, sombras, ensangrentados. El autor nos describe con todo detalle el gran terror de la infeliz protagonista, cargando las tintas en aquellos aspectos que más miedo podían causar a sus ingenuos y confiados lectores y lectoras de principios del siglo XIX:

A tan funestos presagios, Elvira, espantada, atónita y llena de terror, se estremece y tiembla en su solitario lecho; quiere lanzarse de él para llamar a su fiel Narcisa; pero por un fatal encanto, su alcoba, guarnecida por todas partes de fuertes barras y de gruesos cerrojos, la ofrece el aspecto de una horrible jaula de hierro, alumbrada por una luz fúnebre colocada frente a una cabeza ensangrentada... La condesa, desfallecida al ver cosas tan terribles, sucumbe al principio a su dolor; su seno, violentamente agitado, no puede contener la turbación que lo oprime, y parece querer lanzarse al corsé que lo tiene cautivo... No puede ver bien el espectro de la muerte que la persigue con aquel aparato infernal; 
pero reuniendo después todas sus fuerzas, se pone a dar gritos, los más penetrantes, que al fin despiertan a Narcisa. (Pérez Zaragoza, 2004: 217)

Ante sus gritos, acude la fiel doncella. Pero el autor aprovecha para aumentar e incrementar los efectos de terror, ante la desaparición ahora de tantos horrores:

Pero como no había quedado ningún vestigio de las terribles imágenes que había visto, y que esta cabeza de sangre, esta lámpara, esta prisión, candados y cerrojos se había todo desvanecido como una nube, Narcisa confirmó que su ama había tenido una penosa visión. (Pérez Zaragoza, 2004: 217)

Pero todo había desaparecido, lo que aumenta el desconsuelo y la desazón de la joven condesa. Regresa el conde al castillo, y se deshace en detalles amorosos hacia la joven esposa a la que colma de regalos. Pero justamente esta insistencia en el deslumbramiento amoroso de la joven, intensifica el clímax de horrores: «ignorando que estrechaba en sus brazos a un monstruo teñido de sangre, que no pensaba sino en darla una muerte lenta...» Pronto la protagonista irá descubriendo, aunque muy paulatinamente, detalles que van revelándole la crueldad y fiereza del marido. Por ejemplo: las joyas que le ha regalado están manchadas de sangre, descubrimiento al que llega tras ir atando cabos sobre el comportamiento del esposo, muy lleno de sospechas:

Estas reflexiones hicieron no poca impresión en el corazón de la condesa, y excitaron en ella la más cruel inquietud: su admiración se redobló justamente al ver todas aquellas alhajas salpicadas de sangre: un grueso rubí estaba cubierto de ella, y habiéndose caído sobre el vestido de la condesa, la salpicó por muchos parajes; después, las letras iniciales árabes que notó tenía la cajita embutidas de oro sobre la tapa, denotaban ser de un propietario extranjero... ¿Qué consecuencia podía sacar de esta particularidad...? (Pérez Zaragoza, 2004: 220)

Llena de terror y confusión, según nos dice el autor, la joven va advirtiendo los peligros que corre sin ahorrar detalles, entre ellos cómo va percibiendo estos peligros, hasta el punto de que advierte que «un olor como de cadáver había afectado a toda la mansión». Para ir aumentando paulatinamente las sensaciones de imparable terror que va sufriendo la protagonista:

la distribución y el mecanismo del castillo le causaban mucha sospecha e inquietud: una idea vaga y dolorosa parecía quererla revelar un misterio atroz, oculto bajo sus pies... y ciertos presentimientos horrorosos la advertían por lo bajo que marchaba sobre féretros ensangrentados. (Pérez Zaragoza, 2004: 221)

Son las diez de la noche de un día de noviembre. Silba el viento, los bosques están cubiertos de nieve, tan sólo se oyen las aves de rapiña. El ambiente no puede ser más espantoso y terrorífico:

¡Qué espectáculo! ¿Qué aislamiento! ¡Qué soledad para un espíritu afectado como el de Elvira...! Añadid a estos objetos tan poco gratos las manadas o cuadrillas de lobos hambrientos que se lanzaban del bosque hasta el puente levadizo, que venían a hacer oír sus 
horrorosos aullidos bajo el balcón de la galería de occidente; los bramidos de los osos que marchan lentamente sus pasos sobre la nieve y más peligrosas aún que estos animales, las caravanas de Kalmucos errantes, acostumbrados a no vivir sino del pillaje, seres acaso más salvajes que las bestias feroces, y que no hacían más que sorprender las casas solitarias... ¿Y podrás, lector mío, formar una idea exacta del sitio en que la fatalidad había colocado a nuestra heroína? (Pérez Zaragoza, 2004: 222)

Tras estos iniciales datos de ambiente, el relato se desarrollará hacia su final de la forma más acelerada posible, intensificando los efectos del terror, aumentando las visiones fantasmagóricas e incrementando toda clase de sonidos atemorizantes. Al mismo tiempo, el conde va dejando claros sus propósitos, que no son otros que asesinar a la familia de la joven princesa y apoderarse de su reino. Y uno de los momentos de mayor terror para la joven, ya reclusa en uno de los aposentos del castillo, se produce cuando descubre la cabeza de su padre, ya asesinado, lo que se combina con misteriosas alteraciones de luz y oscuridad en su aposento, reflejos de cadáveres en los espejos, miembros ensangrentados y fantasmas cubiertos de grandes túnicas blancas que llenan de terror a la protagonista, y, desde luego, a sus lectores y lectoras. Ya que llegaremos a saber, cuando el cuento esté próximo a su fin, y el conde no haya conseguido sus propósitos de asesinar a Elvira, que todo estaba dispuesto para aterrorizar a la muchacha:

el infernal castillo no era... más que un juego de trampas, tramoyas, fantasmas y espíritus artificiales, unidos a las maravillas de la óptica y de unas luces, manejado todo por cómplices asalariados, para darles movimientos en los techos, o por dobles ensambladuras disimuladas, o con puerta de cigüeñales que representan en pintura espectros, para dar aire maravilloso y sobrehumano a todo cuanto encerraba aquella caverna de tigres... (Pérez Zaragoza, 2004: 234)

Ni que decir tiene que al final será el justo el que triunfe. Dourlinski morirá cuando lleguen en auxilio de los oprimidos tropas enviadas desde San Petersburgo y el castillo será incendiado y pulverizado, como lugar infecto en donde tantos crímenes se había cometido.

Sin duda, estamos ante un relato muy de su tiempo, que responde a modas que tuvieron mucha difusión en la literatura europea del momento, caracterizadas por la utilización de lo misterioso y de lo maravilloso, la acumulación de efectos de terror, presencia de seres sobrehumanos y fantasmagóricos, acciones inexplicables y misteriosas, y ruidos ensordecedores difíciles de identificar. Si a todo ello se une la presencia de una muchacha ingenua, inocente, desvalida y engañada, que, en su delicadeza y debilidad, sufre todos los avatares producidos por los terroríficos elementos que la rodean y la acosan, tendremos ante nosotros los más genuinos ingredientes de la llamada novela gótica, productora incansable de espacios de terror y de pánico en su tiempo en toda la Europa de comienzos del Romanticismo.

Y ya que de Romanticismo hablamos, no podemos dejar de mencionar a Gustavo Adolfo Bécquer, uno de nuestros grandes poetas de todos los tiempos, pero también gran narrador a través de sus inolvidables Leyendas, en las que lo misterioso, los sobrenatural, lo inexplicable, juega muy importante papel, aunque nunca llegan a ser auténticos relatos de terror. Pero también están sus Cartas desde mi celda, mucho menos conocidas, entre las que se halla algún relato, que podríamos calificar de fantástico y de terror. En la selección de cuentos de terror que manejamos, se escogió una carta, la octava, sin duda 
característica de la literatura de su tiempo y de la imaginación de su autor, en la que el miedo juega también un papel decisivo.

Bécquer, que escribe sus cartas desde el casi abandonado Monasterio de Veruela, donde está recluido para pasar una temporada y mejorar sus salud, cuyo destino es su publicación en El Contemporáneo, periódico de Madrid, donde aparecen en el verano de 1864, no duda en crear el ambiente fantástico adecuado para enmarcar el relato que una de las mujeres del servicio del monasterio le ha contado. Y así propicia la ambientación adecuada:

Las diez de la noche acababan de sonar en el antiguo reloj de pared, único resto del mobiliario de los frailes, y solamente se oían, con breves intervalos de silencio profundo, esos ruidos apenas perceptibles y propios de un edificio deshabitado e inmenso, que producen el aire que gime, los techos que crujen, las puertas que rechinan y los animaluchos de toda calaña que vagan a su placer por todos los sótanos, las bóvedas y las galerías del monasterio... (Bécquer, 2004: 191)

Y la moza del pueblo le cuenta una de las leyendas del pueblo de Tresmoz, en el que ejercía su sagrado ministerio un cura muy bueno que había logrado con sus exorcismos ahuyentar las brujas de un próximo castillo e impedir sus maleficios sobre la gente del pueblo. Hasta que por muerte de un hermano viene a vivir con él la que él creía que iba a ser consuelo de su vejez, una muchacha de dieciocho años, modesta en principio, pero que ante la proximidad de la fiesta mayor del pueblo, ve con envidia cómo se engalanan todas sus vecinas, cosen nuevos vestidos, preparan alhajas, mientras que ella, dada la pobreza del cura, no puede prepararse ninguna gala para la fiesta. Hasta que un día comienzan los prodigios e intervienen los poderes sobrenaturales, tal como nos cuenta magistralmente el genial Bécquer:

Sentada estaba, pues, a la puerta de su casa la malhumorada sobrina del cura, barajando en su imaginación mil desagradables pensamientos, cuando acertó a pasar por la calle una vieja muy llena de jirones y de andrajos que, agobiada por el peso de la edad, caminaba apoyándose en un palito. (Bécquer, 2004: 195)

Como advertimos, el ambiente está ya creado, y la sola presencia de la vieja nos hace estremecer, sobre todo cuando comprobamos siguiendo el relato que, al pedirle una limosna a la muchacha, ésta no le hace el menor caso, y así una y otra vez. Pero la vieja, dulcificando su desagradable voz de carraca inicia una lenta aproximación a la muchacha para convencerla de que puede darle todo lo que ella quiera si estuviere dispuesta a servir a «un señor poderoso como el de Mosén Gil», es decir el mismísimo diablo, aunque en ningún momento lo nombra Bécquer, pero sí sus cualidades, cantadas con entusiasmo por la vieja:

Los que le adoran viven en una continua zambra, tienen cuantas joyas y dijes desean y poseen filtros de una virtud tal que con ellos llevan a cabo cosas sobrenaturales; se hacen obedecer de los espíritus, del Sol y de la Luna, de los peñascos, de los montes y de las olas del mar le infunden el amor o el aborrecimiento en quien mejor les cuadra. Si quieres ser de los suyos, si quieres gozar de cuanto ambicionas, a muy poca costa puedes conseguirlo... (Bécquer, 2004: 196) 
Y le propone un acuerdo consistente en cambiar el agua bendita con la que cada noche el cura hacía exorcismo al pueblo para evitar las brujas por un brebaje diabólico que le entrega. Bécquer intensifica el ambiente de lo fantástico y misterioso:

\begin{abstract}
Si sustituyes aquélla agua con ésta y después de apagado el hogar dejas las tenazas envueltas en las cenizas, yo vendré a verte por la chimenea al toque de ánimas, y el señor a quien obedezco, y que en muestra de su generosidad te envía este anillo, te dará cuanto desees. (Bécquer, 2004: 200)
\end{abstract}

Y así lo hace la moza, y así se cumple. En la noche antes de la fiesta, descienden por la chimenea un gran número de gatos, hasta catorce o quince, y un número aún mayor de pequeños sapos, que se convierten aquéllos en hacendosas muchachas que confeccionarán los vestidos más lujosos y éstos en artesanos que llevarán a cabo las joyas más elegantes y las zapatillas más delicadas, con las que acudirá, una vez dormido el cura, a la fiesta la muchacha siendo la envidia de todas sus vecinas, y logrando un pretendiente de los más ricos y bien dispuestos de la localidad con el que en efecto se casará. Pero el maleficio está hecho, como relata muy bien Gustavo Adolfo Bécquer:

Las brujas, con grande asombro suyo y de sus feligreses, tornaron a aposentarse en el castillo; las jóvenes del lugar se veían atacadas de enfermedades incomprensibles; los niños eran azotados por la noche en sus cunas, y los sábados, después que la campana de la iglesia dejaba oír el toque de ánimas, unas sonando panderos, otras añafiles o castañuelas, y todas a caballo sobre sus escobas, los habitantes de Trasmoz veían pasar una bandada de viejas, espesa como las grullas, que iban a celebrar sus endiablados ritos a la sombra de los muros y de la ruinosa atalaya que corona la cumbre del monte. (Bécquer, 2004: 201)

Como vemos, sin insistir de una manera decidida en aspectos terroríficos, Bécquer logra crear un ambiente fantástico que en algunos momentos refleja un cierto temor. Como el que experimenta la muchacha al hacer punto por punto todo lo que la bruja le pide, como así reconoce Bécquer, cuando indica que «temblaba» siguiendo las instrucciones, ante la surgencia de los gatos y sapos por la chimenea, sobre todo cuando la muchacha advierte en el gato que parecía hacer de jefe, un gato gris, en cuyos ojillos «verdosos y fosforescentes» cree reconocer los de la misma bruja. El ambiente de la llegada de los gatos y sapos no puede ser más conseguido, cuando describe a todos los gatos danzando por la habitación y a los pequeños sapos «verdes y tripudos con un cascabel al cuello y una a manera de casaquilla roja», que «daban volteretas en el aire o hacían equilibrios y dislocaciones pasmosas, como los clowns de nuestros circos ecuestres». $\mathrm{O}$ en el momento en que acepta el conjuro que el gato-jefe le propone: «Haz tres veces la señal de la cruz con la mano izquierda, invocando la trinidad de los infiernos: Belcebú, Astarot y Belial.»

Perteneciente a la misma época que Bécquer, aunque concebido de una forma más realista, más de la vida urbana, que caracterizó a sus novelas, con personajes reales, cotidianos, propios de la nueva novela que su generación creó, el relato «La mujer alta», de Pedro Antonio de Alarcón, representa muy bien su literatura de terror, que el novelista decimonónico cultivó con gran acierto. «La mujer alta» pertenece a sus Narraciones inverosímiles, y, según Rafael Llopis, «es uno de los mejores cuentos de miedo, si no el mejor de toda la literatura española». 
El cuento está montado sobre una estructura de marco, ya que quien lo relata es Gabriel, ingeniero de montes, a sus compañeros de expedición, en un lugar no identificado de la Sierra de Guadarrama, a legua y media de El Escorial, en el límite divisorio de las provincias de Madrid y Segovia:

Os contaré una rara y peregrina historia en comprobación de mi tesis... reducida a manifestar, aunque me llaméis oscurantista, que en el globo terráneo ocurren todavía cosas sobrenaturales: esto es, cosas que no caben en la cuadrícula de la razón, de la ciencia, ni de la filosofía, tal como hoy se entiende (o no se entienden) semejantes palabras, palabras y palabras que diría Hamlet... (Alarcón, 2004: 177)

A pesar de considerarse «un hombre a la moderna, nada supersticioso, y tan positivista como el que más», refiere a sus compañeros de excursión una historia «singularísima» dice él, acaecida a otro ingeniero, éste de caminos, llamado Telesforo X, al que algunos contertulios dicen reconocer, y que murió en 1860. Sabemos que la excursión ocurre el día de Santiago o el de San Luis de 1875 (25 de julio o 25 de agosto), por tanto.

Telesforo, joven ingeniero, pierde a su novia, de muy mala salud, y su amigo va a verlo al lugar del trabajo (proyecta en este momento con sus ayudantes un ferrocarril), y enlutado le recibe, le aparta de los demás y se dispone a contarle a nuestro narrador Gabriel que le ocurre «una cosa particular y muy extraña» y que quiere hablarle de «una circunstancia horrenda y misteriosa que ha servido como agüero infernal a esta desventura, y que tiene conturbado mi espíritu hasta un extremo que te dará espanto...». Como vemos, Pedro Antonio de Alarcón no ahorra adjetivos y expresiones extremas para crear el ambiente propicio que va integrando al lector en el espacio del miedo, del terror...

Manifiesta el joven ingeniero a su amigo que nada hay en este mundo que le cause tanto «horror y susto» «como una mujer, sola, en la calle, a altas horas de la noche». Y, tras asegurar que durante su vida han sido muchos los peligros que ha sorteado, demostrando ser un hombre de valor en muchas y variadas ocasiones, nada hay que le dé más miedo que esa mujer alta:

Pero si el bulto era de una mujer sola, parada o andando, y yo iba también solo, y no se veía más llama viviente por ningún lado... entonces (ríete si se te antoja, pero créeme) poníaseme la carne de gallina; vagos temores asaltaban mi espíritu; pensaba en almas del otro mundo, en seres fantásticos, en todas las invenciones supersticiosas que me hacía reír en cualquier otra circunstancia, y apretaba el paso, o me volvía atrás, sin que ya se me quitara el susto ni pudiera distraerme un momento hasta que me veía dentro de mi casa. (Alarcón, 2004: 179)

Se introduce el narrador en el relato de las apariciones que serán objeto del cuento. $\mathrm{Y}$, en efecto, relata el joven ingeniero que una noche, la del 15 al 16 de noviembre de 1857 para ser exactos, yendo por las calles del centro de Madrid, en concreto por la calle de la Montera, cuando salía de tugurio en el que había perdido mucho dinero, inmunda sala de juego a la que había acudido por primera vez, y en la que se arruinó de un golpe. Con este pesar, y sobre todo pensando en su anciano padre, al que habría de pedir dinero para sobrevivir tiene lugar la primera aparición, que el ingeniero recuerda con pavor, espantado, pero con todo detalle: 
al pasar por delante de una casa recién construida de la cera que yo llevaba, advertí que en el hueco de su cerrada puerta estaba de pie, inmóvil y rígida, como si fuese de palo, una mujer muy alta y fuerte, como de sesenta años de edad, cuyos malignos y audaces ojos sin pestañas se clavaron en los míos como dos puñales, mientras de su desdentada boca me hizo una mueca horrible por vía de sonrisa... (Alarcón, 2004: 183)

Naturalmente, el ingeniero alude al «terror» y «delirante miedo» que de él se apoderó, intentado recordar más detalles de la visión espantosa de esa mujer alta y solitaria, descarnada de hombros, marchitos ojos de búho, saliente nariz, gran mella en su dentadura, etc. Avanza rápido nuestro ingeniero, pasa por delante de la mujer alta sin tan siquiera mirarla, y cuando ha transcurrido un breve espacio vuelve la cabeza por ver si lo sigue la mujer y, ante su sorpresa, la lleva pegada a sí mismo, casi tocándole con un abanico que la vieja portaba, de manera que echa a correr, como un niño hasta llegar a la calle más ancha de la Montera. Encuentra a un sereno, le pide que le ayude, logra llegar a su casa, y cuando allí llega, el criado le espera despierto para anunciarle que un amigo, comandante Falcón, ha venido a verlo y que regresará de madrugada para traerle una noticia. No lo duda, nuestro ingeniero, esa es la señal de que su padre, anciano, ha muerto en Jaén, como en efecto se confirmará cuando llegue el amigo con la fatal noticia.

El terror del cuento continúa. Porque tres años después, unas semanas antes del momento del relato, el joven ingeniero vuelve a encontrar a la mujer alta, otra vez de madrugada, otra vez en las estrechas calles del centro de Madrid, esta vez entre la calle del Prado y la del Lobo, entre la plaza de las Cortes y la de Santa Ana:

Vuélvome en esto... y íallí estaba! íAllí, a mi espalda, casi tocándome con sus ropas, mirándome con sus viles ojuelos, mostrándome la asquerosa mella de su dentadura, abanicándose irrisoriamente, como si se burlara de mi pueril espanto!... (Alarcón, 2004: 185)

Se sucede a continuación un forcejeo, y, tras él, un diálogo con la mujer alta empezando ella a quejarse de la manía que le había tomado el ingeniero, recordarle cuándo se vieron tres años antes, $\mathrm{y}$, finalmente, identificarse como el demonio. El terror y el espanto de nuestro ingeniero se suceden y cuando logra alcanzar su casa, de nuevo el comandante (ya coronel) Falcón acude para, de nuevo, traerle una mala noticia: la muerte de su novia, Joaquina, en Santa Águeda, el día anterior.

Y el cuento no termina aquí con sus horrores. Todavía tendrá una especie de coda o continuación final. La noticia de la muerte de Telesforo, tras una breve enfermedad de ictericia, y la asistencia de nuestro ingeniero narrador a su entierro, a que también asiste la famosa mujer alta:

llamó mi atención una mujer del pueblo, vieja, y muy alta, que se reía impíamente al ver bajar el féretro, y que luego se colocó en ademán de triunfo delante de los enterradores, señalándoles con un abanico muy pequeño la galería que debían seguir para llegar a la abierta tumba...

A la primera ojeada reconocí, con asombro y pavura, que era la implacable enemiga de Telesforo, tal como él me la había retratado, con su enorme nariz, con sus infernales ojos, con su asquerosa mella, con su pañolejo de percal y con aquel diminuto abanico, que parecía en sus manos el cetro del impudor y de la mofa... (Alarcón, 2004: 187) 
Indudablemente, el cuento de Pedro Antonio de Alarcón reúne los elementos más característicos de la literatura de terror, entre los que hay que destacar cómo, de los tres narradores del relato -el narrador omnisciente, Gabriel, el ingeniero de Montes, y Telesforo, el ingeniero de caminos-, no sólo se ve implicado en la historia truculenta Telesforo, ya que es su protagonista, sino que también el segundo narrador se verá envuelto en la maravilla y el miedo, al tener ocasión de conocer a la mujer alta en el no menos terrorífico espacio del cementerio durante el entierro de su amigo. El narrador omnisciente, permanece al margen, limitándose a concluir la historia, expresando la admiración de los concurrentes a la excursión de Guadarrama con la que se abre el relato.

Otros elementos destacables y admirablemente manejados por Alarcón son las descripciones del personaje que infunde el terror, que son detalladas y reiteradas, así como el relato de sus apariciones, movimientos y, sobre todo, su conversación con la pobre víctima, que queda aún más horrorizada, ante el desparpajo con que se desenvuelve, y se identifica, la aparición. Sin duda, el elemento terrorífico mayor es hacer coincidir la aparición de la mujer con sendas muertes de seres queridos del ingeniero Telesforo, y con la del propio protagonista el día de su entierro haciéndose visible al narrador secundario de la historia. Con toda razón, y por esta y otras muchas razones, este cuento se considera un clásico del género en España.

La selección que utilizamos cuenta con dos representaciones de la literatura española del siglo XX del máximo interés, a pesar de tratarse de dos escritores hoy muy olvidados, pero de indudable mérito. Uno de ellos es Wenceslao Fernández Flórez, nacido en La Coruña en 1887 y muerto en Madrid en 1964, conocido sobre todo por su literatura humorística. Escritor seguidor de la tradición gallega de lo mágico, de lo fantástico, a la que pertenecerían entre otros Emilia Pardo Bazán, Ramón María del Vallle-Inclán o Camilo José Cela, fue autor de novelas como El bosque animado, y de libros como Fantasmas artificiales y Tragedias de la vida vulgar, en el que aparece recogido este cuento, titulado «El claro del bosque», que puede ser un buen ejemplo de la literatura de miedo y de terror, fantástica y mágica del siglo XX.

Los elementos que pone en funcionamiento Fernández Flórez para llevar a cabo su relato son, en primer lugar, un paisaje, un bosque gallego muy oscuro y poblado, feraz e intrincado, en cuyo interior hay un pequeño y reducido claro donde se encuentra la casa que será escenario de los acontecimientos sucedidos en el cuento, una casa blanca y pequeña, que de pronto es hallada por el protagonista y narrador del cuento, Mauricio, un peregrino a Santiago de Compostela que pretende refugiarse en esa casa una noche oscura y lluviosa, fría y destemplada del otoño gallego.

Otro de los elementos que inducen más al temor de sus lectores son los personajes: en primer lugar el propio peregrino, Mauricio, habitante de una casita junto al río Sil, que se dirige en peregrinación al apóstol para curar su insoportable insomnio, víctima de negros presagios que no le permiten conciliar en ningún momento su reposo. Y, por otro lado, los habitantes que hay en la casa aislada y solitaria: el dueño, Ricardo Mans, un hombre rudo y directo, sus misteriosas hijas, y otro peregrino, un hombre tullido e imposibilitado, que también viaja hacia Compostela. Las descripciones de Fernández Flórez son expresivas, directas y atemorizantes, llenas de hondo misterio y de negros presagios. Así, las tres hijas:

Las tres hijas del dueño, sentadas en tres taburetes de metal, me miraron. Las tres eran pálidas, delgadas y tristes; las tres tenían unos grandes ojos negros como las sombras del bosque, y el mismo ademán recogido; sobre sus trajes de luto las manos cruzadas 
ponían una idéntica mancha de blancura. Las tres hijas saludaron con la voz lenta. Llamábanse Octavia, Ofelia y Otilia. (Fernández Flórez, 2004: 206)

Desde luego, la más enigmática, y a la que corresponderá un importante papel en el desarrollo del relato, será Octavia, descrita con imágenes sobrenaturales:

Octavia tenía los labios rojos como si rezumase sangre la suave piel, en la que brillaba un reflejo de la hoguera. Sentada en medio de sus hermanas, no me miró al entrar, pero mis ojos pecadores la envolvieron largo tiempo en una mirada. (Fernández Flórez, 2004: 268)

Y es que al protagonista narrador le recuerda haberla visto previamente, lo que empieza a torturarle y al final esta obsesión se convertirá en el centro argumental de todo el relato. Otro personaje descrito con tintas crudas y desnudas es el imposibilitado, que luego sabremos que se llama Senén, sorprendentemente descubierto junto a la lumbre cuando el peregrino llega a la modesta cabaña:

Miré. Un hombrecillo sin piernas, con la abultada barriga protegida a ras del suelo por una funda de cuero, me sonreía. Tenía la cabeza redonda y, en lo sumo, los escasos cabellos grises alborotados daban la ilusión, en su tenuidad breve humo que vacilase en desprenderse de ella. Cerca de sus manos estaban los tarugos de madera claveteada que servía para impelir su cuerpo mutilado, arrastrándose por la tierra. La blusa, que era todo su traje, tenía el mismo color que el carro manchado de barro en que se asentaba. (Fernández Flórez, 2004: 268)

El ambiente y las acciones de los personajes también provocan escalofríos. Así, cuando la comida está preparada, las muchachas se disponen a servirla: «Se movían sin hablar, casi sin ruido, con cierta vaguedad en los grandes ojos, tras los párpados semiabiertos, como si durmieran, como si sus almas estuviesen lejanas y no quisiesen volver. El narrador protagonista, prendado del misterio y el embrujo de la mirada de la hija mayor, acentuará el nivel de intriga, cuando reitere una pregunta que pondrá en guardia al lector, inquietándole y perturbándole hasta el estremecimiento: «¿Dónde había visto yo una mirada igual, la misma lucecita de misterio, la misma fiebre...?» ... «¿Dónde había conocido a la hija de Ricardo Mans?» Pero quizá el momento de mayor expectación y estremecimiento para el lector es cuando el peregrino confiesa cuál es su mal, tras haber sido invitado a dormir en una buena cama preparada por las muchachas. Le produce entonces la clave central del terror del cuento, en la que reside todo su argumento: el insomnio, el insomnio lleno de negros presagios que le hará al personaje recorrer espacios fantásticos y terroríficos, sin control racional, perdido en inquietantes ambigüedades:

Yo no puedo dormir. Hace un mes que no se han cerrado mis ojos más que para la meditación de mi desdicha. Una noche he tenido una terrible pesadilla. Al despertar, no quedaba en mí ni el más leve recuerdo. Pero todo estoy invadido de espanto desde entonces. La pesadilla truncada me espera para volver a torturarme, y mi alma lo sabe y no quiere huir del refugio de mi triste cuerpo, temerosa de que en el sueño la acerque y oprima otra vez el monstruo que la ha estremecido. Yo no pudo dormir; todo en mí es profunda fatiga. Hace un mes que me envuelve este terror. A veces creo que mis pies no tocan el suelo, porque el cansancio ha ido matando mis nervios. (Fernández Flórez, 2004: 269) 
Pero lo peor viene cuando el dueño de la casa, al oír estas revelaciones y confirmar que el peregrino no puede dormir, y, después de que el mutilado, siguiendo la tradición ancestral lo atribuye a los Malos Espíritus, expulsa al viajero de su cálido hogar: «Entonces tú estás embrujado. Debes irte. No consentiré nunca que un embrujado pase la noche bajo el mismo techo que yo.»

Y el relato camina hacia su desenlace. Cuenta el protagonista narrador su salida de la casa, acompañado de la enigmática Octavia cuyos ojos quedan grabados en su memoria, su peregrinar por el bosque que le llevará a una fantástica ciudad desierta, sin habitante alguno, en la que volverá a encontrar al tullido Senén:

Me senté en el umbral, desfallecido. Os juro que no puede darse una más terrible impresión que la de esta soledad persistente en el corazón de una ciudad desierta. ¿Qué misterio guardarían todas aquellas casa herméticas? ¿Qué horror gigantesco se había ocultado en ellas? (Fernández Flórez, 2004: 273)

Pero el terror va en incremento cuanto el tullido Senén revela a Mauricio que las hijas de Ricardo Mans están eternamente dormidas, y mientras parecía que se calentaban al fuego, en realidad sus almas vagan por los espacios, porque se dice que han hecho un pacto demoníaco:

Sus sueños no son vaguedad sino realidades; gozan y sienten más intensamente que si estuviesen desiertas. Y así viven una vida maravillosa. Ellas buscan sus sueños. Los demás tenemos los que nuestras almas tropiezan en su camino, cuando nos abandonan. A veces ellas juegan también con nuestros espíritus. Los acechan, invisibles junto a nuestras camas, y, dormidos ya, se adueñan de ellos y los torturan o los inundan de felicidad. En ocasiones son tan terribles sus caprichos que nuestras almas, atemorizadas, no dejan nuestro cuerpo dormir. (Fernández Flórez, 2004: 275)

De pronto, una voz se oye al lado de Mauricio: «¿Y qué sabe ese viejo de sueños ruines...? Y es Octavia, la que aparece, mientras ciñe con su brazo el cuello de nuestro protagonista narrador con el que inicia un diálogo espeluznante de reconocimiento, en el que le confirma que ella es la mujer de su pesadilla, la que tantas veces ha visto en sueños en su choza, la que llena de terror su alma, la que ha querido beber su sangre, en un sueños angustiosos, la que no le va a permitir dormir. Y, en el diálogo que entre ellos hay, se oyen reproches y anhelos, hallazgos y reconocimientos, entre palabras de amor y atracción fatal, que arrebatan a Mauricio y lo hacen suspenderse en el vacío mientras siente, en contacto con la blanda y melosa Octavia, un frío fatal:

Y unió su cara a mi piel, sobre mi corazón. Yo acariciaba las sortijas de su melena. Pero el frío sutil creció. Lo sentía ahora ya sobre mi pecho, sobre mi corazón. Bruscamente, el terror de mi pesadilla volvió a acometerme. Di un rápido empellón a Octavia y corrí, desaforado, enloquecido, jadeando de miedo. Corría, corría en un esfuerzo desesperado pero, como en los sueños, mis pies no se apartaban de aquel lugar; era como si la tierra corriese también debajo de mí, y los árboles que rodeaban el claro guardasen también la distancia. Sentada a mis pies, la mujer esperaba sonriendo, con sus ojos terribles, y con los labios sangrientos. Al fin, caí rendido, roto, dando unos débiles aullidos de temor. Y los blandos brazos me acogieron y volvió a hundirse el pálido rostro en la abertura de mi sayal, sobe mi corazón. (Fernández Flórez, 2004: 278) 
Y, como conclusión del cuento, el narrador protagonista, preso de su amada misteriosa, ceñido por su delgado cuerpo, intenta gritar pero no puede; le invade un sopor, una dulzura y una inconsciencia, sus pies comienzan a enfriarse sobre la hierba húmeda del claro, y sólo le queda pensar en las palabras del tullido, en la muerte y exclamar: «Quizá haya de amanecer muerto... Y nadie sabrá...»

Como hemos podido advertir, todos los materiales narrativos manejados por Fernández Flórez han ido en busca de la creación de un clima especial de terror, de misterio, de magia, y para ello han contribuido de forma especial no sólo los singulares y estremecedores escenarios, no sólo los peculiares y singulares personajes, sino toda la representación de los sueños, de la imaginación, el ambiguo convivir de lo real con lo fantástico, en la creencia de que seres sobrenaturales pueden poblar nuestro mundo y de que el alma abandona el cuerpo durante el sueño para volver a él al despertar. Y que, cuando está fuera del cuerpo, el alma puede ser protagonista de sucesos extraordinarios, víctima de espíritus maléficos, objeto inocente de apariciones y encuentros, sorprendentes espacios ignorados en los que reina lo insospechado y lo terrorífico.

El último relato al que nos vamos a referir pertenece al escritor español Noel Clarasó (1899-1985), se titula «El jardín de Montarto» y fue integrado en su libro Miedo. Se trata de un texto muy distinto de los anteriores, ya que no es estrictamente un historia de terror, sino un espeluznante relato en el que se cuenta la historia de una visión maravillosa de un paisaje ignoto, que ocurre a un joven muchos años atrás del momento en que se relata el cuento. Para ello se sirve Clarasó de una estructura de tres narradores que nos van a ir suministrando los elementos maravillosos y sorprendentes, verdaderamente sobrenaturales de esta historia.

Nos cuenta el narrador omnisciente, una persona joven, que un día «hace años», un joven descendía de la cumbre del Montarto, a la que solía subir de excursión y que, por cierto, conocía bastante bien. Al llegar a su albergue inicia conversación con un anciano que le relata cómo él, cuando era joven, había recorrido muchas veces con su padre toda la cumbre del Montarto, y, que ya siendo algo mayor, y deseando hacerse cazador de gamuzas, especie común en la fauna de aquellas cumbres, convence a su padre para que lo deje ir sólo a cazar. Terminado el invierno y comenzando el deshielo, una noche sale el joven futuro cazador para apostarse en condiciones de conseguir buena caza y así convencer a su padre de que sería en el futuro un buen cazador. Pero lo que le acontece al muchacho es algo muy distinto. De pronto se ve envuelto en una gran oscuridad, ante un espacio cubierto de espesa niebla que se va alejando delante de él conforme avanza. Sucede esto durante una buena porción de tiempo, pasan algunas horas, y no sólo no amanece sino que la niebla continúa y le va rodeando, de manera que él sigue caminando, sobre una fina hierba, por la que sus pies iban muy cómodos, pero ya sin piedras ni recodos propios de un relieve montañoso, hasta que empieza a aparecer una luz muy extraña, que ilumina todo el paraje, se disipa la niebla y encuentra un hermosos jardín.

El relato de Clarasó logra convertir ahora, por virtud de su amenidad y expresividad, los espacios en lugares maravillosos, sorprendentes, llenos de misterio y de fantasía:

La niebla se levantó lentamente, como gasas de seda sopladas por el viento. La vi cómo se replegaba hacia los lados. Era como si se descorriera una serie de cortinajes blancos. Pronto quedó completamente despejado el espacio, y me encontré con el paisaje más raro y más inesperado.

Era una gran extensión de prado, cubierto de hierba tupida, con algunos árboles enor- 
mes esparcidos como en un jardín. Los árboles estaban muy separados unos de otros, pero había muchos, porque en la lejanía hacia los bordes de mi campo visual y en las cuatro direcciones sus troncos hacían como un muro que no dejaba ver más lejos.

Vi formas blancas lejanas que se movían entre los troncos. No eran formas humanas. Eran como gasas o desgarrones de niebla. Esto no me llamó mucho la atención, porque a veces la niebla se pasea sí entre los árboles. Es un fenómeno curioso que sólo sorprende la primera vez y yo lo había visto otras veces. (Clarasó, 2004: 344)

Así lo cuenta el viejo al joven excursionista, que continúa con la descripción detallada de aquel espacio maravilloso, en el que también encuentra un hermoso lago de aguas azules, pero transparentes, de una temperatura ideal, que al tocarla, a pesar de su intenso color azul, no tintaba las manos. Continuando hallará plantaciones distribuidas como en un jardín espléndido en el que verá plantas desconocidas con flores rojas muy extrañas, una de las cuales cortará y prenderá a la hebilla de su cinturón. Examinando árboles y observando todo, entra a nuestro aventurero una gran paz y placidez y, tumbado sobre la hierba de una pequeña elevación, contempla todas las maravillosas plantaciones que hay a su alrededor:

Recuerdo que me entró como una gran pesantez y que dejé de pensar, pero sin cerrar los ojos. No sentía hambre ni sed, frío ni calor. Y me entró el pensamiento y la impresión del amor. No sé cómo explicarlo. ¿No te pasa alguna vez, ahora que eres tan joven, que te entra el amor sin tener una mujer al lado? No piensas en ninguna mujer y es como si amaras a todas. Y no deseas que se te acerque una porque temes que su presencia real destruirá tu gran sensación de amor. ... Pero allí, aquel día, vino una mujer a mi lado y no me molestó, porque no era una mujer como las otras. ... Era una mujer que no se puede comparar con las otras, con las de aquí abajo. La amé tanto que no he podido olvidarla jamás... Estuvo conmigo y se dejó acariciar y besar. No me dijo nada pero tampoco se opuso a nada. Cuando la toqué sentí un estremecimiento tan fuerte que pensé morir... Con aquella todo era amor. Y estuve con ella hasta que mi cuerpo se agotó y cerré los ojos y entonces sí que me dormí de verdad. (Clarasó, 2004: 347)

Permaneció todavía algún tiempo en aquel lugar hasta que recordó que debería regresar. Se vio de nuevo envuelto en la niebla y, al salir de ella, se encontró de nuevo en un lugar conocido, la montaña en la que se pretendía apostar para cazar las gamuzas. Regresó a su pueblo, y encontró a su padre y a sus vecinos muy alarmados porque hacía cuatro días que había desaparecido, habían organizado partidas para buscarlo en la montaña y no lo habían hallado. A nadie contó sus visiones. Volvió muchas veces al lugar y jamás pudo traspasar al umbral de lo fantástico, aunque sabía muy bien que todo lo ocurrido había sido real porque conservaba la flor, que escondió en un viejo libro, y que, muchos años después, habría de enseñar al joven excursionista al que le estaba relatando la visión.

No termina aquí el relato, y Noel Clarasó amplía la intriga de su historia al propio excursionista que a partir de entonces tratará de encontrar el lugar en el que el viejo había traspasado de la realidad a la fantasía y a la magia de los espacios amenos y maravillosos del jardín deseado. Así lo hace en muchas ocasiones, hasta que, dos años después, el pobre viejo muere, y esa misma noche, una noche de mayo precisamente, recién iniciado el deshielo, sube el excursionista a la montaña y encuentra la niebla que tantas veces había 
ansiado, y que le habría de transportar al jardín maravilloso, en el que encontraría la paz y la tranquilidad que le había anunciado el viejo e incluso a la bellísima mujer. Recoge muestra de hierba, de plantas, de las maravillosas flores rojas. El relato se repite casi exactamente:

Después se sentó a esperar en un montículo de hierba. Estaba un poco mareado por el perfume intenso y no sentía hambre, ni sed, ni calor, ni frío. Le pareció que le entraba una vaga sensación de sueño y, de pronto, le pareció que el corazón le saltaba en el pecho y comprendió algo inexplicable de la verdadera esencia del amor.

Llegó la mujer y estuvo allí con él. Él le quiso hablar y no le salieron las palabras. Se sintió unido a ella de una manera indefinible, y después de un largo agotamiento, se desvaneció. (Clarasó, 2004: 349)

Y como al viejo, lo mismo le ocurre al regresar. Lleva a un amigo botánico las muestras para analizarlas y los resultados advierten que son especies vegetales absolutamente desconocidas, de manera que su profesor de botánica casi le tiene por un loco.

Y el relato llega a su fin con la intervención del narrador que asegura conocer al joven forastero que le había contado las historias y que ya era viejo. El narrador esperará pacientemente su muerte, y esa noche acudirá a la montaña a encontrar él también el jardín de Montarto:

Él lo sabe y le gusta la idea. Dice que su alma me acompañará. Pero no me asusta porque sé que no la veré ni la sentiré. Y también sé que después de haber estado cuatro días en el jardín, con la mujer misteriosa, ya no me faltará nada para ser feliz hasta la muerte. Pero antes buscaré a un joven que me guste y le contaré esta historia. (Clarasó, 2004: 353)

Exactamente como le había ocurrido a sus dos antecesores. Así el relato queda abierto para ser continuado con nuestra imaginación y figurarnos, estremeciéndonos, que algún día podremos encontrar esa niebla que nos transporte al maravilloso, al espléndido y ameno jardín de Montarto.

\section{BIBLIOGRAFÍA}

Alarcón, Pedro Antonio de (1974): «La mujer alta». En: Narraciones inverosímiles, Obras completas. Jorge Campos (ed.). Madrid: Aguilar.

Bécquer Gustavo Adolfo (2002): Cartas desde mi celda, Jesús Rubio Jiménez (ed.). Madrid: Cátedra.

Clarasó, Noel (1976): «El jardín de Montarto». En: Miedo. Barcelona: Libros Reno.

Fernández Flórez, Wenceslao (1969): «El claro del bosque». En: Tragedias de la vida vulgar (Cuentos tristes). Madrid: Aguilar.

Llopis, Rafael (2004): Antología de cuentos de terror. Madrid: Alianza Editorial.

Pérez Zaragoza, Agustín (1977): «La princesa de Lipno o el retrete del placer criminal». En: Galería fúnebre de espectros y sombras, Luis Alberto de Cuenca (ed.). Madrid: Editora Nacional.

Vega Lope de (1973): «La posada de mal hospedaje». En: El peregrino en su patria. Juan Bautista Avalle-Arce (ed.). Madrid: Clásicos Castalia. 


\section{ŠPANSKA KNJIŽEVNOST GROZE: PREBIRANJE NEKAJ RESNIČNO SRHLJIVIH KRATKIH ZGODB}

Španska književnost groze ni bila zelo poznana niti cenjena. Rafael Llopis je v klasični antologiji zbral primere iz različnih književnosti, med njimi nekaj zgodb, ki so jih napisali Śpanci Lope de Vega, Agustín Pérez Zaragoza, Gustavo Adolfo Bécquer, Pedro Antonio de Alarcón, Fernández Flórez in Noél Clarasó. Avtor v članku opiše njihove značilnosti in prikaže razvoj te zvrsti: prizorišč, oseb, sloga in predvsem literarnih elementov, ki ustvarjajo negotovost, strah in grozo. 